Nataša Sokolov Milovančević ${ }^{1}$

Aleksandar Gračanac ${ }^{2}$

University "Union - Nikola Tesla"

Faculty of Business and Law, Belgrade

Ana Kitić3

University of Nis

Faculty of Mechanical Engineering
SCIENTIFIC REVIEW ARTICLE

doi:10.5937/ekonomika1901057M

Received November, 19, 2018

Accepted: February, 15, 2019

\title{
LEADRESHIP IN SERBIAN HEALTHCARE SYSTEM
}

\begin{abstract}
BackgroundlAim. To discuss current challenges and future perspectives in order to initiate a debate on the introduction of leadership in Serbia's health care system. The ultimate goal of the review is to provide a ground work on which future standardized training and credentialing curriculum could be based on. The PubMed and Web of Science databases were searched in December 2017 and January 2018 for scientific papers written in English using the keywords: health systems, management, leadership, medical education. Health care issues have been the subject of intense scientific discussions around the world for the past two decades. Most attention is drawn to the efforts of interested countries to find the most effective way of managing complex health care systems. There is evidence that management is important and that in successful management, the effects are correlated with management practices and promoted values. The situation where heads of health care teams of large clinical systems in Serbia are physicians, requires more attention to be paid to managerial and leadership skills. Clinical quality depends on employee team work, therefore leadership and management skills are necessary at all levels. The development of leadership competencies must be an integral part of the training and eductation of doctors in Serbia. There is currently a great necessity of a standardized curriculum to be developed and applyed with training and certification of current and future leaders.
\end{abstract}

Key words: health systems: management; leadership; medical education.

JEL classification: $I 1, \mathrm{I15}, \mathrm{O1}, \mathrm{O5}$

\section{ЛИДЕРСТВО У СИСТЕМУ ЗДРАВСТА У СРБИЈИ}

\begin{abstract}
Апстракт
Разговарати о актуелним изазовима и будуцุим перспективама како би иницирала дебату о увођењу лидерства у српском здравственом систему. Крајњи ичиљ је пружање основног рада на којем би се могло заснивати будуцุи
\end{abstract}

\footnotetext{
${ }^{1}$ natasasokolov@gmail.com

${ }^{2}$ aleksandar.gracanac@ppf.edu.rs

${ }^{3}$ kitic.ana4@gmail.com
} 
стандардизовани програм обуке и акредитације. Датотеке ПубМед и Веб оф Сциенце претражене су у децембру 2017. и јануару 2018. за научне радове написане на енглеском користеции кључне речи: здравствени системи, менаимент, лидерство, медицинско образовање. Питања здравствене заитите су предмет интензивних научних дискусија ииром света у последње две деценије. Највеи́у пажну посвеиује напорима заинтересованих земаља да нађу најефикаснији начин управљања комплексним здравственим системима. Постоје докази да да је менаиемнт важан, и да су ефекти у корелащији са праксомм у менацемнту и вредностима које се промовишу. Ситуација у којој су руководиоци здравствених тимова великих клиничких система у Србији лекари, захтева више пажне на менацерске и лидерске вештине. Клинички квалитет зависи од рада тимског особља, стога су потребне лидерске и менаиерске вештине на свим нивоима. Развој лидерских компетенција мора бити саставни део обуке и едукације лекара у Србији. Тренутно постоји велика потреба за развијањем и применом стандардизираног наставног плана и програма с обуком и сертификаиијом садашњих и будуйих лидера.

Кључне речи: менацемент, вођство, медицинска едукација

\section{Introduction/ Background}

Nations around the world organize and develop their health systems in accordance with their own needs and resources, which leads to great differences in experience and understanding. A good health system brings quality services to people around the world, whenever and wherever the need arises. Services themselves vary on a country basis, but generally require a robust funding mechanism; a qualified and financially satisifed labour; reliable information behind decisions and policies; adequate facilities and logistics to provide quality medicines and technologies (Ferre et al., 2014; Daniels et. al., 2017). The quality of health care in the Balkan countries today is far lower than the European average (Buttigieg et. al., 2016). The health care system of Serbia has the highest number of employees in the region, but it allocates the least money for the sector (Al Jazeera Balkans, 2018). As health care costs today are rising faster than the costs of other services, providers of health services in Serbia, especially the hospitals, are under constant pressure. The main challenges are increased costs and variations in quality. A major concern is also the return of invested funds. Faced with the financial crisis and fear of the unsustainability of the health system, there is a constant pressure from the authorities to reduce costs, although resources are becoming more expensive and the patients' expectations are increasing. The migration of medical personnel from Serbia is becoming a trend; the consequences are obvious and the expectations are unfavorable. The results of the research "Migration of health workers from the Western Balkans countries - analysis of the causes, consequences and policies" recently published by the Institute of Public Health of Serbia showed that health care workers on the way to other countries are mostly forced by low income, inability to get employed, job dissatisfaction, and by the position of doctors in the society, followed by the lack of conditions for professional development and career development, poor working conditions, poor organization and nepotism(Institute of Public Health of Serbia "Dr Milan 
Jovanović Batut." Migration of health workers from the Western Balkans countries analysis of causes, consequences and policies 2017). In order to tackle the challenges that the health system in Serbia faces today, a deep understanding of the resulting situation, the response of the competent authorities, the planned actions of the scientific community, and the concrete contribution of all stakeholders are needed. These are difficult decisions, and it is unclear what the right or acceptable solution is and what is not in such specific areas of human practice.

\section{Methodology}

The PubMed and Web of Science databases were searched in December 2017 and January 2018 for scientific papers written in English using the keywords: health systems, management, leadership, medical education.

\section{Discussion}

Based on the review of available literature, this article discusses knowledge flows on how management can affect the quality and sustainability of health systems and organizations. Health care service provider issues have been the subject of intense scientific discussions around the world for the past two decades. Most attention is paid to the efforts of interested countries to find out the most effective way of managing complex health care systems. There is a belief that management is important and that in successful management, the effects are correlated with management practices and promoted values (Goodall 2011). Recent studies have highly underlined the importance of governance in the health sector: a positive correlation between clinical and economic performance has been found; management can affect the quality and sustainability of health systems and organizations. (Fitzgerald 2015)

Of course, there are still many open questions, including the topic of managing a complex health care system. Globally, the view that medical organizations run by doctors are working better than others is dominant. The following benefits of medical engagement are highlighted: lower patient mortality rates, less serious incidents, maintenance of high level of service delivery and patient care, good financial status, achievement of set goals, maintenance of basic standards (Macinati et al., 2016). In Serbia, the healthcare system is traditionally administered by doctors. The Law on Health Care from 2010 allows the appointment of non-medical professionals as directors if the training on health services management has been successfully completed. This raises important questions about the role that doctors can and should have in creating the future of medicine in Serbia. There are a lot of dilemmas about how to increase, support and invest in the development of leadership and managerial skills. Scientific experts express doubt and warn that such efforts will not be enough unless accompanied by clear and long-term development of managerial skills through well-designed and regular education. Such education should not be an addition to the already complex process of medical education and training (Sarto, Veronesi 2016).

Leadership and governance are two different entities. Not all leaders are managers and not all managers are leaders. The manager focuses on systems and structure, the 
leader focuses on people. Management means developing formal plans and monitoring results. Leadership deals with confronting change and establishing a vision. The ability for medical (clinical) leadership and management should be considered as an essential part of the development of professional competence among doctors, addressed at all levels of their training. Medical leadership is a key part of the professional work of a doctor, regardless of specialty and appointment. Therefore, doctors in Serbia should be more actively involved in the planning, provision and transformation of health services (Xenikou, 2017). It is their duty to contribute to the development of the institution in which they work and to fulfill what society needs in the future. It is a way for a doctor to stay in touch with clinical reality, and at the same time to plan its future in the form of new ideas and current projects. This would also contribute to the integration of clinical and managerial interventions that the complex needs of health systems require today (Macinati et. al., 2016).

In recent years, especially due to the pressures of financial crisis, there is an increasingly obvious need for a broader perspective on the quality of health services. It seems that clinicians and managers can no longer work in isolation, because every manager-clinician conflict is regularly transformed into a competition for resources. Managers and clinicians in Serbia are aware of this and tend to integrate operational and clinical processes. It is not enough for clinicians to act only as practitioners in their discipline. It has become obvious that they have to act today as partners by accepting the shared responsibility for the success of the organization and its services. Groups are often more loyal to the leader than the manager. Why? A leader is followed naturally, whereas managers have to be respected. Only working together, the leadership of a health organization can provide the quality health care needed today: in a holistic and integrated way. Natural disasters, which have been common in the past decade, provide the best example of how clinicians and managers can act synergistically (Sterbenz., Chung 2017).

At the macroeconomic level, health is a factor that has direct implications for the proper conduct of life and economic and social activity. Health is "the collective value of a higher interest" (Lacronikue, 2005). The health of each individual and the nation is directly proportional to their quality of life. The quality of life is defined as the perception of individuals about their own position in life in the context of the culture and system of values in which they live, as well as according to their goals, expectations, standards and interests. It is a broad concept made up of individuals' physical health, psychological status, financial independence, social relations and their relationship to significant environmental characteristics. Our consciousness is the one that principally shapes quality of life, health, and ability. What people people more and more strive for is inner satisfaction. Happiness is the primary goal of human existence (Lega, Sartirana 2017). At the international level, welfare improvements are increasingly seen as an alternative to increasing gross national product (GNP) as a measure of progress and the nation's goal. Well-being is well beyond any good (Bocelli 1938). One of the leading nations in the debate on welfare policy is Britain where Parliament established working groups for the welfare economy, which points to the view that well-being has become an arena for political debate. The UK government launched in 2015 a new advisory center based on evidence of well-known "What Works". The purpose of the Center is to provide guidance to national, regional and local policy makers and other stakeholders on best 
welfare improvements in the UK, and to encourage stakeholders to make decisions based on the impact of different political options on the welfare of the nation (Kirkpatrick et al., 2016)

Currently everything happens 20 times faster than a few decades ago. Our spiritual growth and maturation are also accelerating, and in addition, healing is faster. However, health care planning is often described as evolutionary rather than revolutionary. The change is the nature of reality. We are all in the path of personal change and the simultaneous changing of the world around us. But no problem can be solved at the same level of consciousness on which it originated (Einstein). This is achieved by gaining insight into his abilities - spiritual development, self-evolution. For the development and training of employees in this direction, the most successful companies in the world allocate as much as ten percent of total income. In Serbia, only about one or two percent is allocated for such needs. Increased awareness and flexibility lead to the revitalization of both personal and professional life, and personal and professional development go hand in hand with each other. Quantum physics has confirmed the importance of the level of consciousness and intent of the individual - the force behind everything created. Therefore, health organizations, wherever they are, should now provide quality health care in a holistic and integrated way with the help of clinicians and managers. The characteristics of quality health care are: efficiency, accessibility, equality, safety and effectiveness. All this with a focus on the patient is a platform in which clinicians and managers can identify clinical and operational processes that would enable them to provide health care in a desirable, comprehensive way. Its major weakness is that it turns holistic medicine into art rather than science because the physician must master the intention, which is a poorly understood dimension of existence. Also, the treatment and management of complex health systems requires a constant compromise between the need to reduce costs and improve the quality of health care, which greatly slows down the process of progress and the expected improvement (Kirkpatrick et al., 2016)

It has become a familiar cry in recent years that more doctors should take up senior management and leadership roles in the health service. Some countries, such as Australia, Canada and the UK, already have medical education and developed competency frameworks for management and leadership. Broader literature on leadership suggests that some leadership behaviors are universally supported, but there are also those that are culturally determined. At the global level, debates are still ongoing, how to coordinate medical education with changing socio-economic needs and organizing health systems. Most health systems continue to face multiple challenges during the management process. For example, the intelligent use of information technology has become essential for effective leadership. Health informatics has developed over the years and is one of the important pillars in providing quality health care. IT systems of the European health sector, compared to other industries, are still not at a desirable level. The challenge of the digital world can not be seen only as a challenge, but as a future perspective (Martin et al. 2015; Spurgeon et. al. 2015)

Doctors in managerial positions are important for hospital performance. The question arises what role they can and should have in creating the future of medicine. Considering the great investment in time and resources necessary for their training, it is reasonable to investigate whether placing future physicians in leadership roles is a valuable investment. There is a prediction that a large number of doctors who now 
perform the tasks of managers will soon retire, and that leadership competencies among young doctors must be developed. The conclusion of the assessment of leadership education indicates that there are serious shortcomings in the number and quality of leader (Savage et. al., 2017; Straus et. al., 2013).

Leaders are those employees who discover new directions for continuation. Therefore, the process of change in Serbian health care should be efficiently and comprehensively addressed, by identifying the leadership potential among employees, by inducing team spirit and the ability to function within the team, by takin into account technological and other non-technological opportunities, such as climate culture and human resources. In order to achieve greater organizational outcomes, knowledge is needed on how to identify a medical leader and how they can support this mission. It is necessary to make smart decisions, not to accept the loss of human resources and to experiment with bad decisions. Evidence of decision-making must be used at all levels tactically, operationally and strategically (Xenikou 2017).

\section{How to recognize the leader}

Leadership is the ability to influence a group towards achieving goals. A leader is a person who is able to understand the common goal, as well as to express the collective intent and will of the group. The effectiveness of leadership comes from the ability of the leader to inspire, communicate and coordinate within the group, solve problems and learn. Leadership is motivation. The style of management manages the motivation, morale and retention of staff. The leader believes in what he is promoting, does not just do it for personal gain, but to help as many people as possible. The team views the team's work as a group synergy. Successful synergy means achieving better results in the team compared to individual results. The vision of the leader and the creative mind leads employees into collective value creation. Meaning, creativity and purpose are the three deepest motivational factors of each human being. These are spiritual contents that make up the essence of spiritual intelligence. Spiritual intelligence is indispensable for many obstacles that managers, leaders and their teams face on daily basis. Self-awareness is the basis of spiritual intelligence. This is what every manager and / or leader must recognize and initiate within his team (Shearrer 2012).

Healthcare in Serbia requires leaders who do not develop their own ego but institutions they manage, who have a holistic approach - a global view of the whole situation that is seen as a whole of related parts - where an individual within the group is enabled to exercise his own personal rhythm, with all its potentials. Personal characteristics of a leader are charisma, enthusiasm, courage, and empathy. In team work, he advocates mutual trust, respect for the ideas of employees and respect for their feelings. If leadership is a motivation, then a person who knows how to motivate can be a leader because he can be trained for leadership. Individuals who do this will appear as leaders who generate performance that is beyond expectations. It may be useful to bear in mind that "willing" unlike "accidental" medical leaders are more capable of "absorbing" or constructing managerial expertise (Tsai et al,. 2015). 


\section{A way forward}

Health care management and leadership is essential, but neglected aspect of medical training in Serbia. Changes in curricula and innovation are inevitable parts of progress in undergraduate and postgraduate studies in medical education. Lack of training promotes poor decision-making and inadequate health services that negatively affect end users. An integrated approach to the management of health care and education of medical leadership at the undergraduate level is needed in order to enable physicians to be effective leaders who manage resources in an appropriate manner and in accordance with quality requirements. The health care system today needs to provide quality health care in a holistic and integrated way with the help of clinicians and managers (Sterbenz et. al., 2017).

Discussions of the future of medical education and the need to include training that allows doctors to contribute to the management, maintenance and reform of health care delivery models, continues the debates that have taken place since the introduction of new public governance reforms. It was found that the leadership of a physician can improve the performance of the health care system in terms of: social responsibility (community contribution), adoption of reforms and information technologies, management of financial and operational resources, quality of care (including health outcomes, patient safety and experience of care) and staff satisfaction and their retention. The situation that physicians at the head of the health care teams of significant clinical systems in Serbia requires that more attention is paid to managerial and leadership skills. What we need to know is why and how to increase, support and directly invest in the development of clinical leadership in Stabia; define the role of a doctor, their organizational and clinical responsibility, and how they can be educated to fulfill what society needs in the future (Bank et. al., 2017).

We have used the approach to finding scientific literature for discussion about how management can affect the quality and sustainability of health systems, all in an effort to draw the attention of competent authorities and stakeholders and initiate their joint action in order to evolve health care in Serbia. Clinical quality depends on interprofessional team work and, therefore, leadership and management skills are needed at all levels. The development of leadership competencies must be an integral part of the training and education of doctors in Serbia. There is currently a great need for a standardized curriculum to be developed and used for training and credentialing of current and future leaders. There is currently a great necessity of standardized curriculum to be developed and applzed with training and certification of current and future leaders. Modification and innovation in curriculum are unavoidable on the road to progress in postgraduate medical education. For the idea of change that adds value to the already existing content it is necessary that the idea is adopted and becomes a routine - standard practice. This requires excellent organizational ability and clinical responsibility in order to create content in practice necessary for Serbian society. Although the implementation of healthcare changes has been known as challenging, change management experts rarely choose to support it. They argue that organizational readiness for change is a critical obstacle to the successful implementation of the initiative for change (Kirkpatrick et al., 2016).

Are we ready? Are Srbian clinical teaching teams ready for changes at organizational level? There is a need to highligth research into readiness for change at a clinical level. 
This article is part of a larger study that focused on issues related to quality, performance and health care management and leadership in the system.

\section{References}

Al Jazeera Balkans. Healthcare status in the region (Serbian) [Internet]. 2018 [cited 2018 Mar 9]. Available from: http://balkans.aljazeera.net/video/stanje-zdravstva-u-regiji

Bank L, Jippes M, Leppink J, Scherpbier AJJA, den Rooyen C, van Luijk SJ, et al. Are they ready? (2017) Organizational readiness for change among clinical teaching teams. Adv Med Educ Pract. 2017; 8: 807-15.

Buttigieg SAC, Gauci D, Dey PK. (2016 January) Business process management in health care: current challenges and future prospects. Innov Entrep Heal.; 3: 1-13.

Daniels K, Connolly S, Ogbonnaya C, Tregaskis O, Bryan ML, Robinson-Pant A, et al. (2017) Democratisation of wellbeing: stakeholder perspectives on policy priorities for improving national wellbeing through paid employment and adult learning. British Journal of Guidance and Counselling.; 1-20.

Ferré F, de Belvis AG, Valerio L, Longhi S, Lazzari A, Fattore G, et al. Italy: Health system review. Health Syst Transit. 2014; 16(4): 1-166.

Fitzgerald L. (2015) How clinical managers (can) improve the health service. Br J Healthc Manag.; 76(7): 378-80.

Goodall AH. (2011) Physician-leaders and hospital performance: Is there an association? Soc Sci Med.; 73(4): 535-9.

Institute of Public Health of Serbia "Dr Milan Jovanović Batut.” (2017 November) Migration of health workers from the Western Balkans countries - analysis of causes, consequences and policies (Serbian). Belgrade;

Kirkpatrick I, Kuhlmann E, Hartley K, Dent M, Lega F. (2016) Medicine and management in European hospitals: a comparative overview. BMC Heal Serv Res [Internet]. 2016; 16 Suppl 2: 171. Available from: https://www.ncbi.nlm.nih. gov/pubmed/27230063

Kirkpatrick I, Veronesi G, Zardini A. (2016) Doctors in management: challenging or reinforcing the professional status order? In: Proceedings of 32 EGOS Colloquium. Naples;

Lega F, Sartirana M. (2016) Making doctors manage $\cdots$ but how? Recent developments in the Italian NHS. BMC Health Serv Res.; 16(2).

Macinati MS, Bozzi S, Rizzo MG. (2016) Budgetary participation and performance: The mediating effects of medical managers' job engagement and self-efficacy. Health Policy (New York).; 2016 120(9): 1017-28.

Martin G, Beech N, MacIntosh R, Bushfield S. (2015) Potential challenges facing distributed leadership in health care: evidence from the UK National Health Service. Sociol Heal Illn [Internet]. 2015; 37(1): 14-29. Available from: http:// onlinelibrary.wiley.com/store/10.1111/1467-9566.12171/asset/shil12171.pdf?v= 1\&t=ieacbulh\&s=2d5aa83bdb41c9db19e96533ab14a06b5d26b635 
Pruitt Z, Mhaskar R, Kane BG, Barraco RD, DeWaay DJ, Rosenau AM, et al. Development of a health care systems curriculum. Adv Med Educ Pract. 2017; 8: 745-53.

Sarto F, Veronesi G. (2016) Clinical leadership and hospital performance: Assessing the evidence base. Vol. 16, BMC Health Services Research.

Savage M, Mazzocato P, Savage C, Brommels M. Physicians' (2017) role in the management and leadership of health care. A scoping review.

Simonović, Z., Simić, V., \& Todorov, J. (2014). Sistem zdravstvenog, penzionog i invalidskog osiguranja poljoprivrednika u Srbiji. Ekonomika, 60(1), 140-147.

Shearer DA. Management styles and motivation. Radiol Manage [Internet]. (2012); 34(5): 47-52. Available from: https://lopes.idm.oclc.org/login?url=http://search. ebscohost.com/login.aspx?direct $=$ true $\& \mathrm{db}=\mathrm{cmedm} \& \mathrm{AN}=23130386 \&$ site $=$ eds live \&scope $=$ site

Spurgeon P, Long P, Clark J, Daly F. (2015) Do we need medical leadership or medical engagement? Leadersh Heal Serv [Internet]. 2015; 28(3): 173-84. Available from: http:/www.emeraldinsight.com/doi/10.1108/LHS-03-2014-0029

Sterbenz JM, Chung KC. (2017) The Affordable Care Act and Its Effects on Physician Leadership: A Qualitative Systematic Review. Vol. 26, Quality Management in Health Care. 2017. p. 177-83.

Straus SE, Soobiah C, Levinson W, E Straus S, Soobiah C, Levinson W. (2013) The impact of leadership training programs on physicians in academic medical centers. Acad Med [Internet]. 2013; 88(5): 710-23. Available from: http://content.wkhealth.com/linkback/openurl?sid=WKPTLP:landingpage\& an $=00001888-201305000-00037$

Tsai TC, Jha AK, Gawande AA, Huckman RS, Bloom N, Sadun R. (2015) Hospital board and management practices are strongly related to hospital performance on clinical quality metrics. Health Aff. 2015; 34(8): 1304-11.

Xenikou A. (2017) Transformational leadership, transactional contingent reward, and organizational identification: The mediating effect of perceived innovation and goal culture orientations. Front Psychol.; 8(OCT). 